\title{
THE EFFECT OF NITROGEN ON THE MICROBIOLOGICAL AND BIOCHEMICAL PROPERTIES OF ZINC-CONTAMINATED SOIL
}

\author{
Rafał STRACHEL, Jadwiga WYSZKOWSKA, Małgorzata BAĆMAGA \\ Department of Microbiology, Faculty of Environmental Management \& Agriculture, \\ University of Warmia and Mazury in Olsztyn, Plac Lodzki 3, 10-727 Olsztyn, Poland
}

Submited 02 Jul. 2015; accepted 26 Apr. 2016

\begin{abstract}
The aim of these studies was to determine the influence of excessive zinc doses on the microbiological and enzymatic properties of soil. Also, an evaluation of the possibility to stimulate remediation processes by nitrogen fertilisation of the soil was attempted. Zinc was applied to loamy sand in the amounts of 0, 250, 500, 750, 1000, $1250 \mathrm{mg}$ $\mathrm{Zn}^{2+} \mathrm{kg}^{-1} \mathrm{DM}$ soil, while nitrogen in the form of urea in doses of $0,250,500 \mathrm{mg} \mathrm{N} \mathrm{kg}{ }^{-1} \mathrm{DM}$ soil. Soil samples were incubated at a temperature of $25^{\circ} \mathrm{C}$, maintaining a constant humidity equal to $50 \%$ of the maximum water capacity. In the $2^{\text {nd }}$ and $20^{\text {th }}$ week of the experiment, the following factors were determined: activity of dehydrogenases and catalase, and number of organotrophic bacteria, copiotrophic bacteria, oligotrophic bacteria, actinomycetes, and fungi. Zinc inhibited the enzymatic activity of the soil, while causing a slight increase in populations of microorganisms. Only fungi reacted unequivocally positively to contamination of the soil with zinc, therefore demonstrating changes in the biodiversity of microorganisms. Nitrogen fertilisation of the soil resulted in stabilization of the environment contaminated with zinc by stimulation of growth of microorganisms resistant to the influence of this metal.
\end{abstract}

Keywords: zinc, soil contamination, enzymatic activity, resistance, resilience, microorganisms, biodiversity, biostimulation.

\section{Introduction}

Excessive presence of toxic compounds, particularly heavy metals, in ecosystems is one of the biggest problems of contemporary environmental protection and related sciences, particularly agriculture. Environmental pollution is a condition in which an introduction of any substance to the biosphere in an amount exceeding the tolerance of the environment results in a disturbance in its proper functioning and the toxicity of this xenobiotic may lead to the death of organisms (Duruibe et al. 2007). The soil contamination depends on, i.a., ground utilisation, the intensity of human activities, the distance from emission sources, and dose of xenobiotics that have been introduced in the past (Luo et al. 2012). The adverse influence of a given heavy metal on the environment and human health results from its mobility in the soil and availability for plants, which by an uptake of trace elements, include them into the trophic chain (Butkus et al. 2004; Kabata-Pendias 2004). Contamination connected with the presence of heavy metals in the soil affects the size of the harvested crop, possibly leading in the longer term to a loss of food security. Examination of the influence of zinc on biological properties is a complex problem because of the fact that this element in small amounts is necessary for proper growth and functioning of living organisms (Chibuike, Obiora 2014). On the other hand, there are reports in the literature concerning the adverse effects of zinc on the microbiological properties of soil, leading to a loss of homeostasis of the environment, and therefore to a disturbance in the processes of matter circulation in ecosystems (Klimek 2012). The issue connected with high amounts of zinc present in the environment occurs commonly nowadays, particularly in the context of areas with a high anthropogenic pressure (Zheng et al. 2010).

Because of their strong relation with cells of living organisms, oxidoreductases are a reliable indicator for the condition of the soil and for changes caused under the pressure of heavy metals (Kizllkaya et al. 2004; Oliveira, Pampulha 2006; Wyszkowska et al. 2006). Long-term mineral fertilisation may positively affect the biochemical properties of soil resulting from the increased proliferation of microorganisms, or it may be a consequence of stimulation of enzymatic activity by the availability of biogenic elements (Jiao et al. 2011).

Corresponding author: Jadwiga Wyszkowska

E-mail: jadwiga.wyszkowska@uwm.edu.pl 
Nitrogen is one of the most important biogenic elements that influence soil fertility and plant growth (Abbasi et al. 2011). Urea fertilisers may induce changes in the biological and physicochemical properties of soil, which is related with the bioavailability of heavy metals, including zinc. The products of urea hydrolysis may form sparingly soluble complexes with zinc present in soil, thus reducing its bioavailability (Jiang et al. 2012). As a result, urea fertilisation may alleviate the adverse effects of zinc contamination on soil biology.

Considering the superior role played by microorganisms in shaping soil fertility, studies on the influence of various doses of zinc on the activity of oxidoreductases, as well as the number and diversity of microorganisms were undertaken, simultaneously taking into account the direction of changes resulting from the retention time of this heavy metal in the soil. Also, suitability of dehydrogenases and catalase activities as an indicator for changes connected with the stress exerted onto the soil microbiome by the presence of toxic substances was examined. Dependencies between the abundance of microorganisms under conditions of a changed environment and changes in the enzymatic activity in time, resulting from their presence in the soil, were considered. In view of the above, our study focused on the biostimulation of zinc-contaminated soil with urea as an additional source of nitrogen. Model experiments were limited to soil fertilization with nitrogen because a more complex fertilization system (e.g. a combination of nitrogen and phosphorus) would make it impossible to reliably evaluate the potential role of nitrogen in reducing the negative effects of the analysed heavy metal. Therefore, the aim of this study was to determine the influence of different nitrogen rates on the microbiological and enzymatic properties of zinc-contaminated soil.

\section{Material and methods}

\subsection{Soil}

In the experiment, brown soil with a granulometric composition of loamy sand (sand, $80.5 \%$; clay, $18 \%$; silt, $1.5 \%$ ) as used, according to WRB (2014) classified among Eutric Cambisols. The soil material was collected from the arable-humic level at the Tomaszkowo Didactic \& Experimental Station belonging to the University of Warmia and Mazury in Olsztyn (north-eastern Poland, 53.71610 N, $20.41670 \mathrm{E})$. The soil was characterized by the following parameters: $\mathrm{pH}$ in $1 \mathrm{M} \mathrm{KCl}-5.6$; $\mathrm{C}_{\text {organic }}-10.0 \mathrm{~g} \mathrm{~kg}^{-1}$ DM soil; $\mathrm{N}_{\text {total }}-0.58 \mathrm{~g} \mathrm{~kg}^{-1} \mathrm{DM}$ soil; bioavailable cations (mg kg-1 DM soil): P - 96.32, K - 179.08, Mg - 50.17; exchangeable cations (mg kg-1 DM soil): $\mathrm{K}-217.73$, Ca $568.60, \mathrm{Na}-100.34, \mathrm{Mg}-64.52$; hydrolytic acidity (HAC) - $18.66 \mathrm{mM}(+) \mathrm{kg}^{-1} \mathrm{DM}$ soil; sum of exchangeable bases cations (TEB) - $40.00 \mathrm{mM}(+) \mathrm{kg}^{-1} \mathrm{DM}$ soil; cation exchange capacity (CEC) - $58.66 \mathrm{mM}(+) \mathrm{kg}^{-1} \mathrm{DM}$ soil; base saturation (BS) - 68.19\%; $\mathrm{Zn}_{\text {total }}-22.68 \mathrm{mg} \mathrm{kg}^{-1} \mathrm{DM}$ soil; $\mathrm{Zn}_{\text {bioavailable }}-9.13 \mathrm{mg} \mathrm{kg}^{-1} \mathrm{DM}$ soil.

\subsection{Experimental design}

The experiment was carried out under laboratory conditions in triplicate. $100 \mathrm{~g}$ of air-dried soil material sieved through a mesh with a diameter of $2 \mathrm{~mm}$ was weighed out to each glass beaker with a volume of $150 \mathrm{~cm}^{3}$. Zinc was applied in the form of an aqueous $\mathrm{ZnCl}_{2}$ solution, in doses corresponding to $0,250,500,750,1000$ and

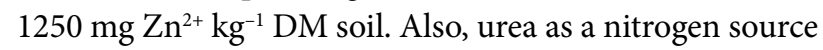
was introduced into the soil samples in the amounts of 0 , 250 and $500 \mathrm{mg} \mathrm{N} \mathrm{kg}^{-1} \mathrm{DM}$ soil. During the experiment, the samples were incubated at a temperature of $25^{\circ} \mathrm{C}$, and the humidity was maintained at the level of $50 \%$ of the maximum water capacity. In the $2^{\text {nd }}$ and $20^{\text {th }}$ week of the experiment, the microbiological and enzymatic properties of soil were determined.

\subsection{Determination of microbial properties and soil enzyme activity}

Populations of microorganisms were determined in triplicate by the spread plate method using the following microbiological media: organotrophic bacteria - a medium with an addition of soil extract according to Bunt and Rovira (1955); oligotrophic and copiotrophic bacteria a medium with a peptone and meat extract according to Onta and Hattori (1983); actinomycetes - Küster and Williams medium with antibiotics (nystatine and actidione) (Parkinson et al. 1971); fungi - on glucose-peptone agar with an addition of rose bengal and aureomycine according to Martin (1950).

Enzymatic analyses of soil, carried out in triplicate, pertained to determination of oxidoreductase activity dehydrogenases (EC 1.1) and catalase (EC 1.11.1.6). Dehydrogenases were determined according to Öhlinger (1996), using 2,3,5-triphenyltetrazolic chloride as a substrate. In the result of metabolic transformations with participation of the tested enzymes, this compound was converted into triphenylformazan. Extinction of the obtained product was measured on a Perkin-Elmer Lambda 25 spectrophotometer using a wavelength of $485 \mathrm{~nm}$. Activity of catalase was determined by a reduction with potassium manganite (VII) of the residue of hydrogen peroxide being a reaction substrate according to Alef and Nannpieri (1998).

\subsection{Calculations}

Diversity of soil microorganisms subjected to impact of zinc was evaluated by the microorganism colony development index (CD) (Sarathchandra et al. 1997) and ecophysiological diversification index (EP) according to the 
formula proposed by De Leij et al. (1993). Abundances of the individual groups of microorganisms was estimated in one-day periods, and based on the changes in the distribution of the developed colonies in time, microbiological diversification of the soil was inferred. A measure for the degree of disturbances caused by the presence of zinc in the soil may consist in determination of resistance index (RS) and index of resilience (RL) proposed by Orwin and Wardle (2004). These indices were calculated based on the oxidoreductase activity.

\subsection{Statistical analysis}

The obtained results of the studies were statistically processed using the Statistica 10.0 (StatSoft 2012) software package, at a significance level of $p=0.01$. According to the requirements of correct statistical inference on the significance of the obtained results, all analyses were carried out in triplicate. Interpretation of effects connected with the presence of zinc in the soil was supported by the following data analyses: percentage of factors of the observed variations $\eta^{2}$, Pearson correlation coefficients $(\mathrm{p}=$ 0.01 ) between the zinc dose and the investigated parameters, cluster analysis (CA) by Ward's method with Euclidean distance in studies of the microorganism populations and principal component analysis (PCA) illustrating the activity of oxidoreductases and community of microorganisms. Homogeneous groups for the colony development index (CD), the ecophysiological diversity index (EP) and the indicators of soil resistance (RS) and soil resilience (RL) were established with the use of Tukey's test and analysis of variance (ANOVA) at a significance level of $\mathrm{p}=0.01$.

\section{Results}

\subsection{Influence of factors}

According to the assumptions made while designing the experiment, the obtained results depended on such factors as the dose of zinc, dose of nitrogen and incubation time of the soil, as well as interaction between the individual factors. Statistical analysis of contribution of the observed variations factors $\eta^{2}$ proved that to the highest degree, the abundance of microorganisms and activity of oxidoreductases depended on contamination of the soil with zinc (Table 1). Only in the case of actinomycetes, the retention time of the metal in the soil turned out to be more important. To a moderate degree, fertilisation with nitrogen affected only growth of organotrophic bacteria, which was conditioned by the interaction between all studied factors to the highest extent. The dependence between the degree of contamination with zinc and the incubation time, also modified the activity of oxidoreductases and population of copiotrophic bacteria.
Table 1. Percentage of the observed variation $\eta^{2}$ in the soil contaminated with zinc

\begin{tabular}{|c|c|c|c|c|c|c|c|}
\hline Variable factors & Cat & Deh & $\mathrm{B}_{\text {org }}$ & $\mathrm{B}_{\text {cop }}$ & $\mathrm{B}_{\text {olig }}$ & Act & Fun \\
\hline Dose of $\mathrm{Zn}$ & 57.08 & 47.96 & 10.99 & 47.62 & 37.83 & 18.35 & 89.45 \\
\hline Dose of $\mathrm{N}$ & 2.11 & 2.80 & 14.57 & 5.78 & 8.32 & 3.47 & 0.08 \\
\hline $\begin{array}{l}\text { Incubation } \\
\text { time }\end{array}$ & 7.79 & 10.36 & 5.14 & 2.22 & 30.97 & 43.87 & 0.49 \\
\hline $\begin{array}{l}\text { Dose of } \mathrm{Znx} \\
\text { dose of } N\end{array}$ & 1.43 & 12.10 & 11.42 & 4.48 & 4.90 & 3.49 & 1.39 \\
\hline $\begin{array}{l}\text { Dose of } \mathrm{Zn} \\
\mathrm{x} \text { incubation } \\
\text { time }\end{array}$ & 21.51 & 22.93 & 12.01 & 20.79 & 0.81 & 12.19 & 2.81 \\
\hline $\begin{array}{l}\text { Dose of } \mathrm{N} \mathrm{x} \\
\text { incubation } \\
\text { time }\end{array}$ & 0.81 & 0.64 & 6.43 & 1.80 & 1.19 & 10.29 & 0.41 \\
\hline $\begin{array}{l}\text { Dose of } \mathrm{Zn} \\
\mathrm{x} \text { dose of } \mathrm{N} \\
\mathrm{x} \text { incubation } \\
\text { time }\end{array}$ & 8.34 & 3.06 & 35.26 & 7.65 & 14.28 & 6.63 & 4.80 \\
\hline Error & 0.94 & 0.14 & 4.18 & 9.65 & 1.70 & 1.71 & 0.57 \\
\hline
\end{tabular}

Explanatory note: $\mathrm{Zn}$ - zinc, $\mathrm{N}$ - nitrogen; Cat - catalase, Deh dehydrogenases, $\mathrm{B}_{\text {org }}$ - organotrophic bacteria, $\mathrm{B}_{\text {cop }}$ - copiotrophic bacteria, $\mathrm{B}_{\text {olig }}$ - oligotrophic bacteria, Act - actinomycetes, Fun - fungi.

\subsection{Microbial properties and enzymes activity}

In soil not fertilised with nitrogen, the colony development indices for organotrophic bacteria and fungi strongly depended on the zinc dose on both dates of the experiment, the $\mathrm{CD}$ index value for bacteria being negatively correlated with the zinc dose, while being positively correlated for fungi (Table 2). The decrease in the value of the $\mathrm{CD}$ index for organotrophic bacteria in the $20^{\text {th }}$ week indicates an inhibited growth of colonies, caused by the contamination of the soil with this metal. In the $2^{\text {nd }}$ week, zinc caused change in the $\mathrm{CD}$ index to a slighter degree, and the index's values suggested that colony development was uniform. On the other hand, while analysing the data pertaining to fungi, it should be stated that zinc improved the development of fastgrowing species. After two weeks, the influence of zinc on the growth of actinomycetes was ambiguous, while in the $20^{\text {th }}$ week, zinc generally caused a decrease in the $\mathrm{CD}$ value. In the objects not contaminated with zinc, but fertilised with urea, an increase in the $\mathrm{CD}$ index occurred for fungi on both dates of the experiment. An inverse dependence was observed for organotrophic bacteria. Additionally, in case of all studied groups of microorganisms, introduction of urea affected the growth rate of colonies positively.

Taking into account the index of ecophysiological diversification of microorganisms, one may ascertain that organotrophic bacteria were developing uniformly during the time of observation (Table 3). It proves a high diversification of the composition of microorganisms. Fertilisation with nitrogen and incubation time of the soil did 
Table 2. Colony development (CD) index for microorganisms in the soil contaminated with zinc (the values are means of three replicates)

\begin{tabular}{|c|c|c|c|c|c|c|c|c|c|}
\hline \multirow{4}{*}{$\begin{array}{l}\text { Dose of } \\
\text { zinc, } \\
\mathrm{mg} \mathrm{Zn}^{2+} \\
\mathrm{kg}^{-1} \mathrm{DM} \\
\text { soil }\end{array}$} & \multicolumn{9}{|c|}{ Microorganisms } \\
\hline & \multicolumn{3}{|c|}{$\mathrm{B}_{\text {org }}$} & \multicolumn{3}{|c|}{ Act } & \multicolumn{3}{|c|}{ Fun } \\
\hline & \multicolumn{9}{|c|}{ Dose of nitrogen, $\mathrm{mg} \mathrm{N} \mathrm{kg}^{-1} \mathrm{DM}$ soil } \\
\hline & 0 & 250 & 500 & 0 & 250 & 500 & 0 & 250 & 500 \\
\hline \multicolumn{10}{|c|}{ Incubation time, 2 weeks } \\
\hline 0 & $51.444^{\mathrm{a}}$ & $46.072^{\mathrm{a}}$ & $37.834^{\mathrm{a}}$ & $21.146^{\mathrm{a}}$ & $22.310^{\mathrm{a}}$ & $19.957^{\mathrm{b}}$ & $31.759^{\mathrm{b}}$ & $39.642^{\mathrm{b}}$ & $35.102^{\mathrm{b}}$ \\
\hline 250 & $41.695^{\mathrm{b}}$ & $44.624^{\mathrm{a}}$ & $39.224^{\mathrm{a}}$ & $25.769^{\mathrm{a}}$ & $25.377^{\mathrm{a}}$ & $25.356^{\mathrm{a}}$ & $45.740^{\mathrm{a}}$ & $45.591^{\mathrm{a}}$ & $46.941^{\mathrm{a}}$ \\
\hline 500 & $43.355^{\mathrm{ab}}$ & $42.855^{\mathrm{a}}$ & $41.849^{\mathrm{a}}$ & $21.585^{\mathrm{a}}$ & $24.323^{\mathrm{a}}$ & $24.511^{\mathrm{a}}$ & $45.836^{\mathrm{a}}$ & $45.370^{\mathrm{a}}$ & $47.189^{\mathrm{a}}$ \\
\hline 750 & $41.080^{\mathrm{b}}$ & $37.796^{\mathrm{a}}$ & $38.102^{\mathrm{a}}$ & $20.849^{\mathrm{a}}$ & $24.369^{\mathrm{a}}$ & $21.400^{\mathrm{ab}}$ & $47.628^{\mathrm{a}}$ & $46.643^{\mathrm{a}}$ & $47.301^{\mathrm{a}}$ \\
\hline 1000 & $35.769^{\mathrm{b}}$ & $36.155^{\mathrm{a}}$ & $37.315^{\mathrm{a}}$ & $23.394^{\mathrm{a}}$ & $22.940^{\mathrm{a}}$ & $24.718^{\mathrm{a}}$ & $45.579^{a}$ & $46.210^{\mathrm{a}}$ & $47.301^{\mathrm{a}}$ \\
\hline 1250 & $40.370^{\mathrm{b}}$ & $42.179^{\mathrm{a}}$ & $41.031^{\mathrm{a}}$ & $22.481^{\mathrm{a}}$ & $22.492^{\mathrm{a}}$ & $22.249^{\mathrm{ab}}$ & $47.441^{\mathrm{a}}$ & $48.115^{\mathrm{a}}$ & $47.735^{\mathrm{a}}$ \\
\hline $\mathrm{r}$ & $-0.707^{\star}$ & -0.544 & 0.128 & -0.022 & -0.199 & 0.142 & $0.679^{*}$ & $0.782^{*}$ & $0.642^{*}$ \\
\hline \multicolumn{10}{|c|}{ Incubation time, 20 weeks } \\
\hline 0 & $58.409^{\mathrm{a}}$ & $22.075^{\mathrm{a}}$ & $19.537^{\mathrm{b}}$ & $27.617^{\mathrm{a}}$ & $21.268^{\mathrm{a}}$ & $21.070^{\mathrm{a}}$ & $39.884^{\mathrm{b}}$ & $43.255^{\mathrm{b}}$ & $43.056^{\mathrm{a}}$ \\
\hline 250 & $37.140^{\mathrm{b}}$ & $18.582^{\mathrm{a}}$ & $22.648^{\mathrm{ab}}$ & $24.043^{\mathrm{a}}$ & $19.178^{\mathrm{a}}$ & $18.923^{\mathrm{a}}$ & $45.503^{\mathrm{a}}$ & $20.054^{c}$ & $28.717^{\mathrm{b}}$ \\
\hline 500 & $24.241^{\mathrm{c}}$ & $26.038^{\mathrm{a}}$ & $24.286^{\mathrm{ab}}$ & $20.042^{\mathrm{a}}$ & $16.532^{\mathrm{a}}$ & $26.199^{a}$ & $46.949^{\mathrm{a}}$ & $47.577^{\mathrm{a}}$ & $46.673^{\mathrm{a}}$ \\
\hline 750 & $26.178^{c}$ & $21.733^{\mathrm{a}}$ & $25.971^{\mathrm{a}}$ & $18.772^{\mathrm{a}}$ & $18.150^{\mathrm{a}}$ & $20.370^{\mathrm{a}}$ & $46.425^{\mathrm{a}}$ & $46.810^{\mathrm{a}}$ & $46.606^{\mathrm{a}}$ \\
\hline 1000 & $21.472^{\mathrm{c}}$ & $24.110^{\mathrm{a}}$ & $20.132^{\mathrm{b}}$ & $18.924^{\mathrm{a}}$ & $19.563^{\mathrm{a}}$ & $22.320^{\mathrm{a}}$ & $46.590^{\mathrm{a}}$ & $45.967^{\mathrm{ab}}$ & $47.769^{\mathrm{a}}$ \\
\hline 1250 & $26.579^{c}$ & $26.972^{\mathrm{a}}$ & $23.356^{\mathrm{ab}}$ & $21.962^{\mathrm{a}}$ & $18.943^{\mathrm{a}}$ & $21.811^{\mathrm{a}}$ & $48.658^{\mathrm{a}}$ & $48.239^{\mathrm{a}}$ & $47.407^{\mathrm{a}}$ \\
\hline $\mathrm{r}$ & $-0.778^{\star}$ & 0.489 & 0.252 & -0.539 & -0.150 & 0.105 & $0.788^{\star}$ & 0.499 & 0.561 \\
\hline
\end{tabular}

Explanatory note: $\mathrm{B}_{\text {org }}$ - organotrophic bacteria, Act - actinomycetes, Fun - fungi. Letter designations (a-c) describe homogeneous groups formed for each groups of microorganisms, dose of nitrogen and incubation time separately. $r$ - coefficient of Pearson's correlation between zinc dose and the analysed parameters, ${ }^{*} \mathrm{p}=0.01, \mathrm{n}=17$.

Table 3. Ecophysiological diversity (EP) index of microorganisms in the soil contaminated with zinc (the values are means of three replicates)

\begin{tabular}{|c|c|c|c|c|c|c|c|c|c|}
\hline \multirow{4}{*}{$\begin{array}{l}\text { Dose of } \\
\text { zinc, } \\
\mathrm{mg} \mathrm{Zn}^{2+} \\
\mathrm{kg}^{-1} \mathrm{DM} \\
\text { soil }\end{array}$} & \multicolumn{9}{|c|}{ Microorganisms } \\
\hline & \multicolumn{3}{|c|}{$\mathrm{B}_{\text {org }}$} & \multicolumn{3}{|c|}{ Act } & \multicolumn{3}{|c|}{ Fun } \\
\hline & \multicolumn{9}{|c|}{ Dose of nitrogen, $\mathrm{mg} \mathrm{N} \mathrm{kg}^{-1} \mathrm{DM}$ soil } \\
\hline & 0 & 250 & 500 & 0 & 250 & 500 & 0 & 250 & 500 \\
\hline \multicolumn{10}{|c|}{ Incubation time, 2 weeks } \\
\hline 0 & $0.693^{\mathrm{a}}$ & $0.794^{\mathrm{a}}$ & $0.808^{\mathrm{a}}$ & $0.754^{\mathrm{a}}$ & $0.765^{\mathrm{a}}$ & $0.775^{\mathrm{a}}$ & $0.667^{\mathrm{a}}$ & $0.509^{\mathrm{a}}$ & $0.509^{\mathrm{a}}$ \\
\hline 250 & $0.718^{\mathrm{a}}$ & $0.793^{\mathrm{a}}$ & $0.824^{\mathrm{a}}$ & $0.816^{\mathrm{a}}$ & $0.797^{\mathrm{a}}$ & $0.807^{\mathrm{a}}$ & $0.282^{\mathrm{b}}$ & $0.311^{\mathrm{b}}$ & $0.307^{\mathrm{b}}$ \\
\hline 500 & $0.749^{\mathrm{a}}$ & $0.740^{\mathrm{a}}$ & $0.606^{\mathrm{a}}$ & $0.753^{\mathrm{a}}$ & $0.777^{\mathrm{a}}$ & $0.781^{\mathrm{a}}$ & $0.270^{\mathrm{b}}$ & $0.268^{\mathrm{bc}}$ & $0.215^{\mathrm{bc}}$ \\
\hline 750 & $0.607^{\mathrm{a}}$ & $0.677^{\mathrm{ab}}$ & $0.627^{\mathrm{a}}$ & $0.757^{\mathrm{a}}$ & $0.803^{\mathrm{a}}$ & $0.813^{\mathrm{a}}$ & $0.178^{\mathrm{b}}$ & $0.227^{\mathrm{bc}}$ & $0.196^{\mathrm{bc}}$ \\
\hline 1000 & $0.702^{\mathrm{a}}$ & $0.728^{\mathrm{ab}}$ & $0.684^{\mathrm{a}}$ & $0.738^{\mathrm{a}}$ & $0.733^{\mathrm{a}}$ & $0.739^{\mathrm{a}}$ & $0.280^{\mathrm{b}}$ & $0.269^{\mathrm{bc}}$ & $0.209^{\mathrm{bc}}$ \\
\hline 1250 & $0.682^{\mathrm{a}}$ & $0.608^{\mathrm{b}}$ & $0.586^{\mathrm{a}}$ & $0.739^{\mathrm{a}}$ & $0.731^{\mathrm{a}}$ & $0.733^{\mathrm{a}}$ & $0.199^{b}$ & $0.161^{\mathrm{c}}$ & $0.187^{c}$ \\
\hline $\mathrm{r}$ & -0.186 & $-0.809^{*}$ & $-0.649^{*}$ & -0.303 & -0.356 & -0.497 & $-0.700^{*}$ & $-0.832^{*}$ & $-0.803^{*}$ \\
\hline \multicolumn{10}{|c|}{ Incubation time, 20 weeks } \\
\hline 0 & $0.721^{\mathrm{c}}$ & $0.751^{\mathrm{a}}$ & $0.752^{\mathrm{ab}}$ & $0.745^{\mathrm{a}}$ & $0.553^{\mathrm{a}}$ & $0.533^{\mathrm{a}}$ & $0.448^{\mathrm{a}}$ & $0.389^{b}$ & $0.305^{\mathrm{a}}$ \\
\hline 250 & $0.872^{\mathrm{a}}$ & $0.734^{\mathrm{a}}$ & $0.815^{\mathrm{a}}$ & $0.774^{\mathrm{a}}$ & $0.512^{\mathrm{a}}$ & $0.503^{\mathrm{a}}$ & $0.311^{\mathrm{b}}$ & $0.686^{\mathrm{a}}$ & $0.445^{\mathrm{a}}$ \\
\hline 500 & $0.801^{\mathrm{abc}}$ & $0.804^{\mathrm{a}}$ & $0.774^{\mathrm{ab}}$ & $0.748^{\mathrm{a}}$ & $0.565^{\mathrm{a}}$ & $0.609^{\mathrm{a}}$ & $0.238^{\mathrm{b}}$ & $0.195^{c}$ & $0.220^{\mathrm{a}}$ \\
\hline 750 & $0.815^{\mathrm{ab}}$ & $0.745^{\mathrm{a}}$ & $0.662^{c}$ & $0.673^{\mathrm{a}}$ & $0.590^{\mathrm{a}}$ & $0.693^{\mathrm{a}}$ & $0.233^{\mathrm{b}}$ & $0.227^{\mathrm{c}}$ & $0.228^{\mathrm{a}}$ \\
\hline 1000 & $0.753^{\mathrm{bc}}$ & $0.776^{\mathrm{a}}$ & $0.735^{\mathrm{ab}}$ & $0.622^{\mathrm{a}}$ & $0.714^{\mathrm{a}}$ & $0.509^{\mathrm{a}}$ & $0.231^{\mathrm{bc}}$ & $0.248^{\mathrm{bc}}$ & $0.180^{\mathrm{a}}$ \\
\hline 1250 & $0.754^{\mathrm{bc}}$ & $0.815^{\mathrm{a}}$ & $0.752^{\mathrm{ab}}$ & $0.526^{\mathrm{a}}$ & $0.686^{\mathrm{a}}$ & $0.570^{\mathrm{a}}$ & $0.124^{c}$ & $0.152^{\mathrm{c}}$ & $0.196^{\mathrm{a}}$ \\
\hline $\mathrm{r}$ & -0.165 & 0.415 & -0.320 & $-0.726^{\star}$ & 0.571 & 0.111 & $-0.894^{*}$ & $-0.653^{\star}$ & -0.560 \\
\hline
\end{tabular}

Explanatory note: $\mathrm{B}_{\text {org }}$ - organotrophic bacteria, Act - actinomycetes, Fun - fungi. Letter designations (a-c) describe homogeneous groups formed for each groups of microorganisms, dose of nitrogen and incubation time separately. $r$ - coefficient of Pearson's correlation between zinc dose and the analysed parameters, ${ }^{*} \mathrm{p}=0.01, \mathrm{n}=17$. 
not affect the changes in EP index of this group of microorganisms significantly. On the first term of the experiment, no significant influence of zinc on the diversity of actinomycetes was found, while a prolonged retention of this metal in the soil not fertilised with nitrogen caused a disturbance in microbiological balance in objects strongly contaminated with zinc. In the $20^{\text {th }}$ week, nitrogen fertilisation of the soil caused a decrease in the diversity of microorganisms unequivocally. In all objects contaminated with zinc, fungi exhibited a small ecophysiological diversity. Low values of the EP index suggest that growth of this group of microorganisms progressed non-uniformly in the studied observation period of colony development.

A decrease in the value of the ecophysiological diversification of fungi, accompanied by an increase in total abundance, suggests growth of species resistant to the impact of zinc. Such changes, occurring as a function of increasing doses of the metal, indicate support for microorganisms with r-type life strategy, being a symptom of a strong disturbance of the given environment.

Based on the created dendrogram by cluster analysis (CA) using the Ward method (Fig. 1), two similarity groups of the response of microorganisms to contamination of the soil with zinc may be distinguished. The first cluster was formed by organotrophic bacteria, copiotrophic bacteria, oligotrophic bacteria and actinomycetes, and the other one by fungi. Within the first main group, subgroups were formed, allowing the ascertainment that on the second term of study, actinomycetes were responding differently from the other groups of microorganisms belonging to the same cluster. It should be emphasised that the similarity

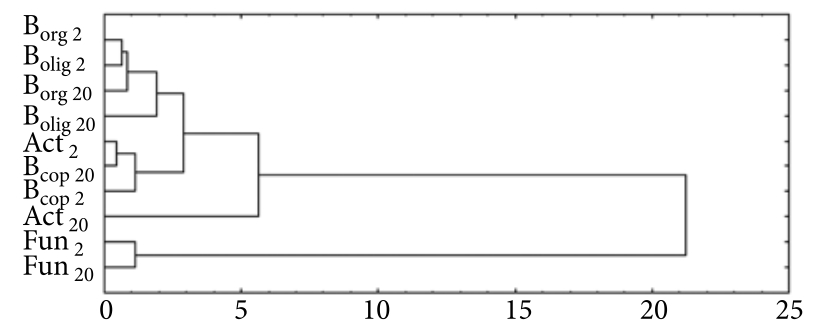

Explanatory note: $\mathrm{B}_{\text {org }}$ - organotrophic bacteria, $\mathrm{B}_{\text {cop }}-$ copiotrophic bacteria, $\mathrm{B}_{\text {olig }}$ - oligotrophic bacteria, Act - actinomycetes, Fun - fungi; incubation time: 2 - 2 weeks, 20 - 20 weeks.

Fig. 1. Cluster analysis (CA) of clusters formed based on the abundance of soil microorganisms subjected to the impact of zinc (irrespectively of nitrogen fertilisation used)

of response to contamination with zinc, between organotrophic bacteria and oligotrophic bacteria was the highest one among the analysed groups of microorganisms. A diversified response of abundances of organotrophic bacteria, oligotrophic bacteria, copiotrophic bacteria and actinomycetes, resulting from the presence of zinc in the soil, was significantly modified by the time the metal exerted its influence. The investigated factors affected the growth of fungi in a different way than in the case of other groups of microorganisms. Various effects of zinc on the individual groups of microorganisms could result from their specific physiological, morphological and genetic properties.

Principal component analysis (PCA) proved that the obtained results of activity of soil enzymes and abundance of microorganisms were modified to more than $46.89 \%$ by the first principal component, while the second component explained $20.27 \%$ of the data variability (Fig. 2).

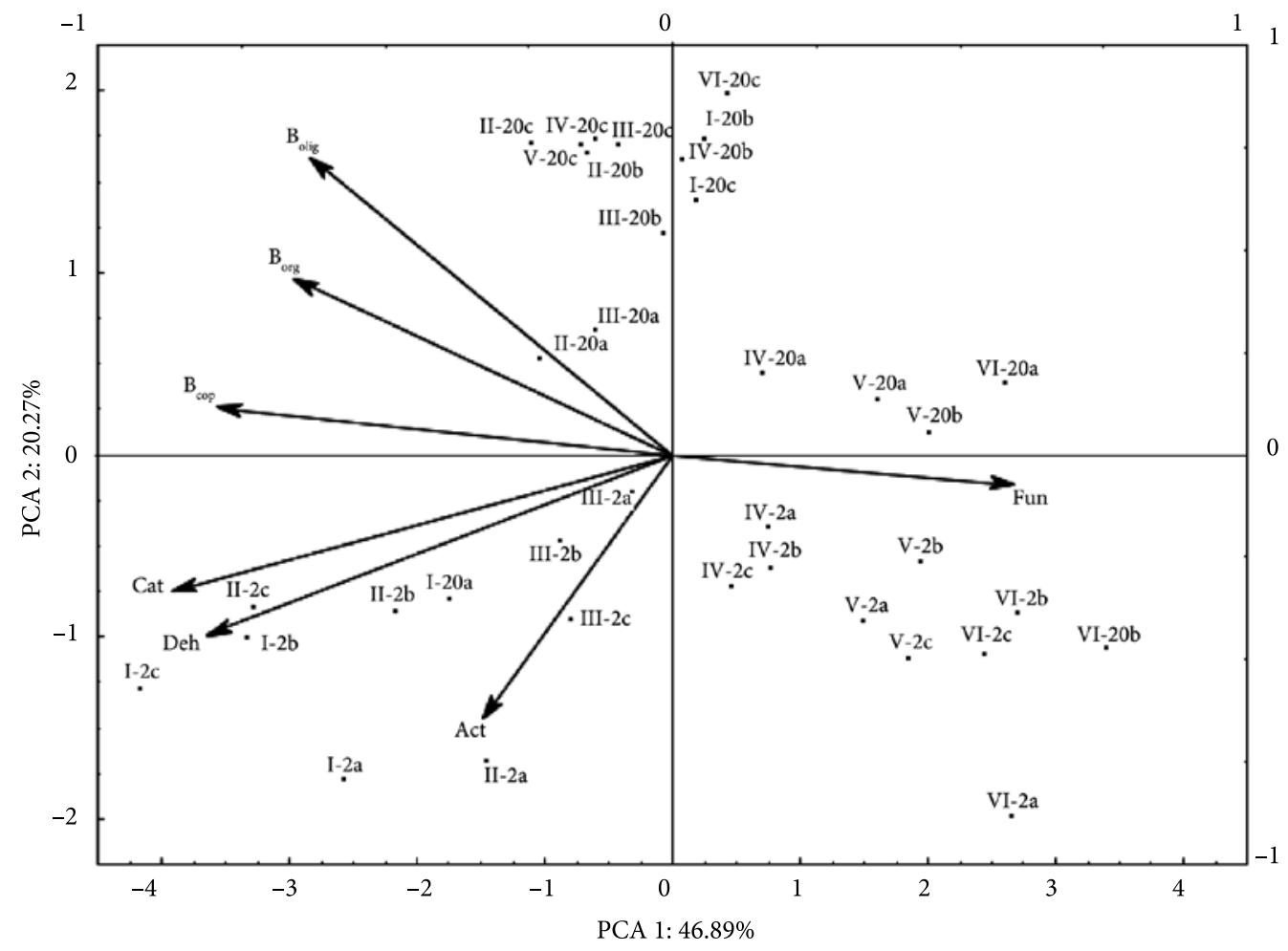

Explanatory note: Cat - catalase, Deh dehydrogenases, $\mathrm{B}_{\text {org }}$ - organotrophic bacteria, $\mathrm{B}_{\text {cop }}$ - copiotrophic bacteria, $\mathrm{B}_{\text {olig }}$ - oligotrophic bacteria, Act - actinomycetes, Fun - fungi; dose of zinc (in $\mathrm{mg}$ $\mathrm{kg}^{-1} \mathrm{DM}$ soil): I - 0, II -250 , III -500 , IV - 750, V - 1000, VI - 1250; incubation time: 2 - 2 weeks, 20 - 20 weeks; dose of nitrogen (in $\mathrm{mg} \mathrm{kg}^{-1}$ DM soil): $\mathrm{a}-0, \mathrm{~b}-$ $250, c-500$.

Fig. 2. Plot of principal component analysis based on soil microbial activity and microbial abundance data 
Analysis of microbiological properties of the soil indicated that a short-term influence of zinc lead to an inhibition in the growth of all tested groups of bacteria. Actinomycetes in the soil not fertilised with nitrogen are an exception. In the studied periods, a dose of zinc equal to $1250 \mathrm{mg} \mathrm{kg}^{-1}$ DM soil caused a decrease in populations of the analysed bacteria groups. The impact of zinc on the populations of Procaryota is ambiguous, because introduction of a dose in the range of 250 up to $1000 \mathrm{mg} \mathrm{Zn}^{2+} \mathrm{kg}^{-1}$ led both to a stimulation and an inhibition of bacterial growth. It depended on the group of studied bacteria, the dose being tested, the retention time of zinc in the soil, and the influence of fertilisation with nitrogen. Moreover, fertilisation with urea affected positively the growth of actinomycetes in objects subjected to a two-week incubation. Stimulation of a multiplication of these microorganisms was observed in the soil contaminated with zinc in the amount of 250 to $750 \mathrm{mg} \mathrm{kg}^{-1} \mathrm{DM}$ soil. However, a prolonged influence of this metal decreased the abundance of this group of microorganisms significantly, and fertilisation with nitrogen did not alleviate adverse effects of zinc presence. Response of fungi to contamination with zinc indicates that they are more resistant to its influence, as their abundance was connected with the used dose of zinc. Abundance of actinomycetes and fungi decreased with an increase in the incubation time of the soil.

The activity of oxidoreductases in the soil indicated a strong influence of the zinc doses applied to the soil. The response of activity of the investigated enzymes was shaped by the studied factors in a similar way, which was indicated by the directions, senses and lengths of vectors describing oxidoreductases. A projection of the cases onto a plane shows that the highest activity of catalase was observed in the $2^{\text {nd }}$ week, while the activity of dehydrogenases was shaped by the whole duration of the experiment.
Distribution of the cases in relation to the vectors describing activity of enzymes indicates that the highest activity is exhibited by enzymes in object not contaminated and in those with an addition of zinc in the amount of $250 \mathrm{mg}$ $\mathrm{Zn}^{2+} \mathrm{kg}$ DM soil. In turn, clusters of cases in the $1^{\text {st }}$ and $4^{\text {th }}$ quadrants suggest that the activity of oxidoreductases was significantly negatively correlated with the zinc dose. Additionally, the distribution of the obtained results was also modified by the duration of the zinc influence and by fertilisation with urea, and the source of nitrogen shaped the biochemical properties of the soil to a lesser extent.

The highest resistance to disturbances in the homeostasis of the soil subjected to the pressure of zinc for 2 weeks, was exhibited by objects contaminated with this metal to the slightest degree (Fig. 3). In case of all combinations, for both tested enzymes, a strong, negatively correlated dependence was occurring between the degree of contamination and the soil resistance. Fertilisation with nitrogen, both in a dose of 250 and $500 \mathrm{mg} \mathrm{N} \mathrm{kg}^{-1} \mathrm{DM}$ soil, increased the resistance of dehydrogenases to zinc significantly. Such dependence was not exhibited by catalase, having a resistance decreased after introduction of urea. Only in the object with the smallest zinc dose (250 mg Zn ${ }^{2+} \mathrm{kg}^{-1} \mathrm{DM}$ soil), a slight positive effect of fertilisation with nitrogen in the amount of $500 \mathrm{mg} \mathrm{kg}^{-1} \mathrm{DM}$ soil was observed.

Based on the differences in the activity of oxidoreductases subjected to the pressure of zinc for 20 weeks, it may be ascertained that the metal caused disturbances in the enzymatic balance of the soil. In the objects not fertilised with urea, the zinc dose equal to $250 \mathrm{mg} \mathrm{kg}^{-1} \mathrm{DM}$ soil exerted a strong adverse effect on catalase, proved by the negative values of the factor $\mathrm{RL}=-0.162$ (Table 4 ). An average value of the RL index in the objects contaminated with zinc without an addition of nitrogen indicates

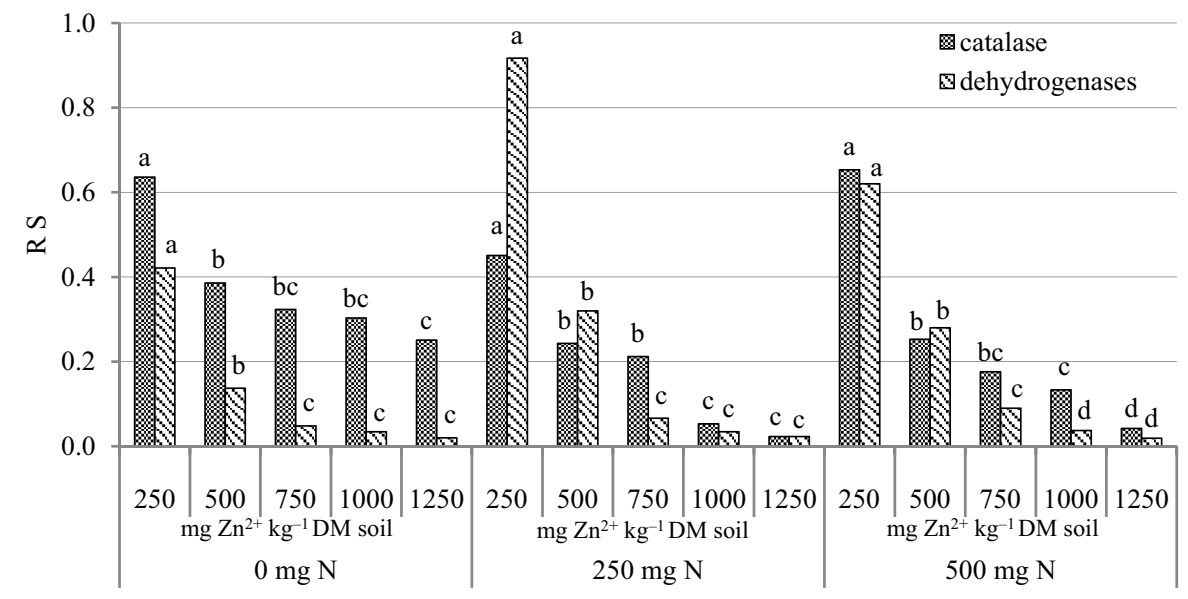

Explanatory note: letter designations (a-d) describe homogeneous groups formed for dehydrogenases, catalase and dose of nitrogen separately.

Fig. 3. Resistance index (RS) of oxidoreductases in the soil contaminated with zinc after two weeks of incubation 
a stronger destructive influence of this metal on the catalase than on that of dehydrogenases. Significant disturbances of this enzyme activity are evident in samples contaminated with zinc in the amounts of 1000 and $1250 \mathrm{mg}$ $\mathrm{Zn}^{2+} \mathrm{kg}^{-1} \mathrm{DM}$ soil. In the object subjected to a slighter pressure of zinc, the stabilisation processes occurred more rapidly. Introduction of nitrogen to the soil, both in the amount of 250 and $500 \mathrm{mg} \mathrm{N} \mathrm{kg} \mathrm{DM}^{-1}$ soil, contributed to a faster restoration of balance of the soil. The RL index assumed values in the range of 0.710 to 0.918 for catalase, and 0.185 to 0.959 for dehydrogenases.

Table 4. Index of resilience (RL) of oxidoreductases in the soil contaminated with zinc after two weeks of incubation (the values are means of three replicates)

\begin{tabular}{|c|c|c|c|c|c|c|}
\hline \multirow{3}{*}{$\begin{array}{c}\text { Dose of } \\
\text { zinc, } \\
\mathrm{mg} \mathrm{Zn}^{2+} \\
\mathrm{kg}^{-1} \mathrm{DM} \\
\text { soil } \\
\end{array}$} & \multicolumn{3}{|c|}{ Catalase } & \multicolumn{3}{|c|}{ Dehydrogenases } \\
\hline & \multicolumn{6}{|c|}{ dose of nitrogen, $\mathrm{mg} \mathrm{N} \mathrm{kg}^{-1} \mathrm{DM}$ soil } \\
\hline & 0 & 250 & 500 & 0 & 250 & 500 \\
\hline 250 & $-0.162^{b}$ & $0.810^{\mathrm{ab}}$ & $0.814^{\mathrm{a}}$ & $0.100^{\mathrm{b}}$ & $0.185^{\mathrm{b}}$ & $0.788^{\mathrm{a}}$ \\
\hline 500 & $0.131^{\mathrm{a}}$ & $0.885^{\mathrm{a}}$ & $0.918^{\mathrm{a}}$ & $0.172^{\mathrm{ab}}$ & $0.782^{\mathrm{a}}$ & $0.854^{\mathrm{a}}$ \\
\hline 750 & $0.185^{\mathrm{a}}$ & $0.855^{\mathrm{a}}$ & $0.916^{\mathrm{a}}$ & $0.212^{\mathrm{a}}$ & $0.741^{\mathrm{a}}$ & $0.809^{\mathrm{a}}$ \\
\hline 1000 & $0.032^{\mathrm{ab}}$ & $0.886^{\mathrm{a}}$ & $0.889^{\mathrm{a}}$ & $0.213^{\mathrm{a}}$ & $0.874^{\mathrm{a}}$ & $0.590^{\mathrm{b}}$ \\
\hline 1250 & $0.071^{\mathrm{ab}}$ & $0.710^{\mathrm{b}}$ & $0.809^{\mathrm{a}}$ & $0.201^{\mathrm{a}}$ & $0.959^{\mathrm{a}}$ & $0.861^{\mathrm{a}}$ \\
\hline Average & 0.051 & 0.829 & 0.869 & 0.180 & 0.708 & 0.781 \\
\hline $\mathrm{r}$ & 0.389 & -0.388 & -0.090 & $0.714^{*}$ & $0.801^{\star}$ & -0.168 \\
\hline
\end{tabular}

Explanatory note: letter designations (a-b) describe homogeneous groups formed for dehydrogenases, catalase and dose of nitrogen separately. $r$ - coefficient of Pearson's correlation between zinc dose and the analysed parameters, ${ }^{\star} \mathrm{p}=0.01, \mathrm{n}=14$.

\section{Discussion}

The microorganisms are characterised by a high ability to adapt to unfavourable conditions in the environment. Reports on the stimulating effect of moderate doses of zinc on the abundance of microorganisms may be found in the literature (Wyszkowska et al. 2013). This is consistent with the obtained results, wherein zinc stimulated the growth of studied groups of microorganisms. It was conditioned by the metal doses used and by fertilisation with nitrogen. Also, in vegetation experiments by Wyszkowska et al. (2006, 2007), zinc applied together with other metals, affected the soil microbiota significantly. Changes in the diversity of fungi, observed in this paper, indicate a significant influence of zinc on this group of microorganisms. Differences in the obtained results may be explained by an impact of other factors which may form the bioavailability of the heavy metal. These factors may include: $\mathrm{pH}$ of soil, sorption capacity, salinity, organic matter (McBride 2003). Nitrogen is a factor that may affect the shaping of soil fertility (Meng et al. 2005) significantly by stimulating the consortium of microorganisms and thus may alleviate adverse effects connected with the presence of toxic substances. As reported in $\mathrm{Yu}$ et al. (2015), fertilisation with urea affects significantly the change in the structure of microorganisms and its function. The authors found an increase in fungi abundance accompanying the increased availability of nitrogen. However, while considering the phenomenon of biostimulation of the microbiome, one should remember that organic matter seems to be the key factor. Influencing the development of the microbiological consortium of the soil, organic matter affects simultaneously an increase in production of enzymes responsible for the biochemical activity of the soil (Jiao et al. 2011). Relating these dependences to the results of microbiological properties obtained in our studies, it should be ascertained that with a low carbon content and a high availability of nitrogen, under conditions of cell stress exerted onto the microorganisms by toxic doses of zinc, proliferation of microorganisms exhibiting a higher resistance to this metal is enhanced. This results from the fact that these microorganisms are able to utilise better the source of available carbon for build-up of their biomass, constituting a labile deposit of this biogenic element in the soil.

The obtained results of the research are consistent with the literature data (Kunito et al. 2001; Castaldi et al. 2004; Mikanova 2006; Yang et al. 2006; Chaperon, Sauvé 2007), which indicate an inhibitive influence of zinc on oxidoreductases. Dehydrogenases are particularly sensitive, and their activity decreases significantly in the soil containing excessive doses of zinc (Chaperon, Sauvé 2007; Kucharski et al. 2011; Borowik et al. 2014a, 2014b). In an amount of

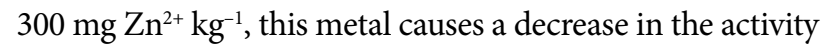
of these enzymes by nearly a half, and its higher doses lead to intensification of changes, as an introduction of $1300 \mathrm{mg}$ $\mathrm{Zn}^{2+} \mathrm{kg}^{-1}$ to the soil, inhibits the activity of dehydrogenases by approximately 70\% (Moreno et al. 2009). In our studies, a significant dependence between the increasing zinc dose and the decrease in the activity of both dehydrogenases, and catalase, was found. Similar conclusions were drawn by Yang et al. (2006), who observed a decrease in the activity of catalase in the soil after introduction of zinc in the amount of 100 to $800 \mathrm{mg} \mathrm{kg}^{-1} \mathrm{DM}$ soil. In model studies, carried out by Borowik et al. (2014a), zinc applied in a dose of 300 to $2400 \mathrm{mg} \mathrm{kg}^{-1} \mathrm{DM}$ soil, decreased the activity of dehydrogenases and catalase, and this dependence was strongly correlated with the dose used. An increase in the soil contamination with zinc was accompanied by an increase in the inhibitive impact of this metal onto the activity of the enzymes, leading to a decrease in the resistance of soil (RS). According to the same authors, $\mathrm{EC}_{50}$ amounted to $689 \mathrm{mg}$

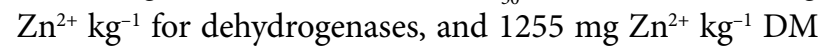
soil in case of catalase. Then, in our studies in samples incubated for 20 weeks, $\mathrm{ED}_{50}$ for dehydrogenases amounted

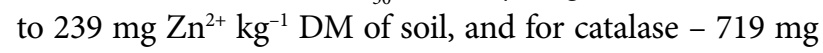
$\mathrm{Zn}^{2+} \mathrm{kg}^{-1} \mathrm{DM}$ soil. 
While pondering biochemical and microbiological properties of soil subjected to pressure from toxic elements, it should be remembered that heavy metals may exert both advantageous and destructive impacts on proper functioning of soils. An excessive amount of the metal may lead to disturbance of cellular processes in the result of affinity of the metal for specific biological structures. This leads to deactivation of a given component, and as a consequence, to an imbalance in cellular homeostasis (Clemens 2006). Tolerance for the presence of heavy metals is an individual feature of various microorganisms. Considering this in respect of biological equilibrium of the soil, growth of microorganisms resistant to strong changes in living conditions takes place at the cost of sensitive microorganisms, which may manifest itself in a reduction of diversity of the given environment (Lock, Janssen 2005). As reported by Jiao et al. (2011), activity of enzymes actually depends on the chemical properties of the soil. Activity of both dehydrogenases and catalase is positively correlated with contents of $\mathrm{C}, \mathrm{N}$ and $\mathrm{P}$ compounds, and with the biomass of microorganisms. In studies of Romero et al. (2010), application of urea did not cause any changes in the activity of dehydrogenases. This lack of stimulation of the microbiome may result from a carbon deficiency, because even with a good availability of nitrogen, growth of microorganisms has been limited by content of carbon source (Bhattacharyya et al. 2005).

The values of microbial activity and abundance indicate that nitrogen fertilisation had a minor effect on the proliferation of microorganisms and oxidoreductase activity, but an important role was played by the interactions between nitrogen fertilisation and the other experimental factors. Soil fertilisation with urea contributed to the narrowing of the C:N ratio, which influenced the soil microbiome, thus accelerating the recovery and restoration of soil to a healthy state.

Availability of nitrogen with a comparatively low carbon content in the soil leads to an increased growth of microorganisms, which are more able to adapt to the change in the environment. Shaping of the microbiome's diversity as a function of time may be related to the enzyme activity, because the RL factor in objects fertilised with urea indicates a biostimulation of microorganisms resistant to the effect of zinc, translating into a decrease in disturbances of biochemical activity, caused by the contamination of the soil environment with zinc. It allows for stating that fertilisation with nitrogen affects the intensification of stabilisation of the soil environment subjected to a heavy metal pressure by promoting proliferation of microorganisms adapted to living in such an environment.

\section{Conclusions}

The abundance of bacteria and actinomycetes was shaped significantly by the content of zinc in the soil. Small doses of this metal exhibited stimulating effect for growth of these microorganisms, but excessive contamination with this metal affected their abundance unequivocally negatively. Fungi were not exhibiting such a tendency, and their abundance was positively correlated with the zinc dose. The incubation time and nitrogen fertilisation of the soil played a significant role as well. Direction and extent of changes induced by these factors depended on the doses applied. Changes in the diversity of microorganisms were also found, most evident in case of fungi. Their growth was positively correlated with the degree of soil contamination, and the pressure exerted by zinc caused a reduction in ecophysiological diversity, indicating a strong loss of the biological balance of the soil.

In the result of the studies, it was proved that zinc inhibited the enzymatic properties of soil for the whole duration of the experiment. Resistance of enzymes strongly depended on the degree of the soil contamination, which is confirmed by negative correlation coefficients. Fertilisation with nitrogen caused acceleration of the balance-restoration processes in the activity of oxidoreductases.

The biological parameters used in the experiment, describing the condition of soil subjected to a pressure of anthropogenic factors, are a useful tool for monitoring of the environment. Thanks to comprehensive investigations, necessary information could be obtained, useful in restoration of biological balance of soil, disturbed by the effect of toxic substances.

\section{Acknowledgements}

The research was supported by the Polish Ministry of Science and Higher Education.

\section{References}

Abbasi, M. K.; Hina, M.; Tahir, M. M. 2011. Effect of Azadirachta indica (neem), sodium thiosulphate and calcium chloride on changes in nitrogen transformations and inhibition of nitrification in soil incubated under laboratory conditions, Chemosphere 82(11): 1629-1635.

https://doi.org/10.1016/j.chemosphere.2010.11.044

Alef, K.; Nannipieri, P. 1998. Methods in applied soil microbiology and biochemistry. London: Academic Press. Harcourt Brace \& Company, Publishers. 576 p.

Bhattacharyya, P.; Chakrabarti, K.; Chakraborty, A. 2005. Microbial biomass and enzyme activities in submerged rice soil amended with municipal solid waste compost and decomposed cow manure, Chemosphere 60(3): 310-318. https://doi.org/10.1016/j.chemosphere.2004.11.097

Borowik, A.; Wyszkowska, J.; Kucharski, J.; Baćmaga, M.; BorosLajszner, E.; Tomkiel, M. 2014a. Sensitivity of soil enzymes to excessive zinc concentrations, Journal of Elementology 19(3): 637-648. https://doi.org/10.5601/jelem.2014.19.2.456

Borowik, A.; Wyszkowska, J.; Kucharski, M.; Kucharski, J. 2014 b. Resistance of dehydrogenases, catalase, urease and plants to 
soil contamination with zinc, Journal of Elementology 19(4): 929-946. https://doi.org/10.5601/jelem.2013.18.4.566

Bunt, J. S.; Rovira, A. D. 1955. Microbiological studies of some subantarctic soils, Journal of Soil Science 6: 119-128. https://doi.org/10.1111/j.1365-2389.1955.tb00836.x

Butkus, D.; Paliulis, D.; Baltrenaite, E. 2004. Sorption of heavy metals from polluted water and their migration in the system soil-tree, Journal of Environmental Engineering and Landscape Management 12(4): 120-125.

Castaldi, S.; Rutigliano, F. A.; Virzo de Santo, A. 2004. Suitability of soil microbial parameters as indicators of heavy metal pollution, Water, Air and Soil Pollution 158(1): 21-35. https://doi.org/10.1023/B:WATE.0000044824.88079.d9

Chaperon, S.; Sauvé, S. 2007. Toxicity interaction of metals (Ag, $\mathrm{Cu}, \mathrm{Hg}, \mathrm{Zn}$ ) to urease and dehydrogenase activities in soils, Soil Biology \& Biochemistry 39(9): 2329-2338. https://doi.org/10.1016/j.soilbio.2007.04.004

Chibuike, G. U.; Obiora, S. C. 2014. Heavy metal polluted soils: effect on plants and bioremediation methods, Applied and Environmental Soil Science. Article ID 752708. https://doi.org/10.1155/2014/752708

Clemens, S. 2006. Evolution and function of phytochelatin synthases, Journal of Plant Physiology 163(3): 319-332. https://doi.org/10.1016/j.jplph.2005.11.010

De Leij, F. A. A. M.; Whipps, J. M.; Lynch, J. M. 1993. The use of colony development for the characterization of bacterial communities in soil and on roots, Microbial Ecology 27: 8197. https://doi.org/10.1007/BF00170116

Duruibe, J. O.; Ogwuegbu, M. O. C.; Egwurugwu, J. N. 2007. Heavy metal pollution and human biotoxic effects, International Journal of Physical Sciences 2(5): 112-118.

Jiang, Z.; Zeng, Q.; Tie, B.; Liao, B.; Pi, H.; Feng, X.; Sun, Y. 2012. Ammonia volatilization and availability of $\mathrm{Cu}, \mathrm{Zn}$ induced by applications of urea with and without coating in soils, Journal of Environmental Sciences 24(1): 177-181.

https://doi.org/10.1016/S1001-0742(11)60742-0

Jiao, X-G.; Gao, C-S.; Lü, G-H.; Sui, Y-Y. 2011. Effect of longterm fertilization on soil enzyme activities under different hydrothermal conditions in Northeast China, Agricultural Sciences in China 10(3): 412-422.

https://doi.org/10.1016/S1671-2927(11)60020-5

Kabata-Pendias, A. 2004. Soil-plant transfer of trace elements an environmental issue, Geoderma 122(2-4): 143-149. https://doi.org/10.1016/j.geoderma.2004.01.004

Kızılkaya, R.; Aşkın, T.; Bayraklı, B.; Sağlam, M. 2004. Microbiological characteristics of soils contaminated with heavy metals, European Journal of Soil Biology 40(2): 95-102. https://doi.org/10.1016/j.ejsobi.2004.10.002

Klimek, B. 2012. Effect of long-term zinc pollution on soil microbial community resistance to repeated contamination, Bulletin of Environmental Contamination and Toxicology 88(4): 617-622. https://doi.org/10.1007/s00128-012-0523-0

Kucharski, J.; Wieczorek, K.; Wyszkowska, J. 2011. Changes in the enzymatic activity in sandy loam soil exposed to zinc pressure, Journal of Elementology 16(4): 577-589. https://doi.org/10.5601/jelem.2011.16.4.07

Kunito, T.; Saeki, K.; Goto, S.; Hayashi, H.; Oyaizu, H.; Matsumoto, S. 2001. Copper and zinc fractions affecting microorganisms in long-term sludge-amended soils, Bioresource Technology 79(2): 135-146. https://doi.org/10.1016/S0960-8524(01)00047-5
Lock, K.; Janssen, C. R. 2005. Influence of soil zinc concentrations on zinc sensitivity and functional diversity of microbial communities, Environmental Pollution 136(2): 275-281. https://doi.org/10.1016/j.envpol.2004.12.038

Luo, X-S.; Yu, S.; Zhu, Y-G.; Li, X-D. 2012. Trace metal contamination in urban soils of China, Science of The Total Environment 421-422: 17-30.

https://doi.org/10.1016/j.scitotenv.2011.04.020

Martin, J. 1950. Use of acid rose bengal and streptomycin in the plate method for estimating soil fungi, Soil Science 69: 215233. https://doi.org/10.1097/00010694-195003000-00006

McBride, M. B. 2003. Toxic metals in sewage sludge-amended soils: has promotion of beneficial use discounted the risks?, Advances in Environmental Research 8(1): 5-19. https://doi.org/10.1016/S1093-0191(02)00141-7

Meng, L.; Ding, W.; Cai, Z. 2005. Long-term application of organic manure and nitrogen fertilizer on $\mathrm{N} 2 \mathrm{O}$ emissions, soil quality and crop production in a sandy loam soil, Soil Biology and Biochemistry 37(11): 2037-2045. https://doi.org/10.1016/j.soilbio.2005.03.007

Mikanova, O. 2006. Effects of heavy metals on some biological parameters, Journal of Geochemical Exploration 88(1-3): 220-223. https://doi.org/10.1016/j.gexplo.2005.08.043

Moreno, L.; Bastida, F.; Ros, M.; Hernández, T.; García, C. 2009. Soil organic carbon buffers heavy metal contamination on semiarid soils: effect of different metal thresholds levels on soil microbial activity, European Journal of Soil Biology 45(3): 220-228. https://doi.org/10.1016/j.ejsobi.2009.02.004

Öhlinger, R. 1996. Dehydrogenase Activity with the Substrate TTC, in F. Schinner, R. Öhlinger, E. Kandeler, R. Mrgesin (Eds.). Methods in soil biology. Berlin Heidelberg: Springer Verlag, 241-243.

Oliveira, A.; Pampulha, M. E. 2006. Effects of long-term heavy metal contamination on soil microbial characteristics, Journal of Bioscience and Bioengineering 102(3): 157-161. https://doi.org/10.1263/jbb.102.157

Onta, H.; Hattori, T. 1983. Oligotrophic bacteria on organic debris and plant roots in paddy field, Soil Biology \& Biochemistry 1: 1-8.

Orwin, K. H.; Wardle, D. A. 2004. New indices for quantifying the resistance and resilience of soil biota to exogenous disturbances, Soil Biology \& Biochemistry 36: 1907-1912. https://doi.org/10.1016/j.soilbio.2004.04.036

Parkinson, D.; Gray, F. R. G.; Williams, S. T. 1971. Methods for studying the ecology of soil microorganisms. IBP Handbook, 19. Oxford, Einburg: Blackweel Scientific Publications. 116 p.

Romero, E.; Fernández-Bayo, J.; Díaz, J. M. C.; Nogales, R. 2010. Enzyme activities and diuron persistence in soil amended with vermicompost derived from spent grape marc and treated with urea, Applied Soil Ecology 44(3): 198-204. https://doi.org/10.1016/j.apsoil.2009.12.006

Sarathchandra, S. U.; Burch G.; Cox, N. R. 1997. Growth patterns of bacterial communities in the rhizoplane and rhizosphere in white clover (Trifolium repens L.) and perennial ryegrass (Lolium perenne L.) in long-term pasture, Applied Soil Ecology 6: 293-299. https://doi.org/10.1016/S0929-1393(97)00015-2

StatSoft Inc. 2012. Statistica (data analysis software system), version 10.0 [online], [cited 02 July 2015]. Available from Internet: www.statsoft.com

World Reference Base for Soil Resources (WRB). 2014. International soil classification system for naming soils and creating 
legends for soil maps. World Soil Resources Reports No. 106. FAO, Rome. $181 \mathrm{p}$.

Wyszkowska, J.; Boros, E.; Kucharski, J. 2007. Effect of interactions between nickel and other heavy metals on the soil microbiological properties, Plant, Soil and Environment 53: 544-552.

Wyszkowska, J.; Borowik, A.; Kucharski, M.; Kucharski, J. 2013. Effect of cadmium, copper and zinc on plants, soil microorganisms and soil enzymes, Journal of Elementology 18(4): 769-796. https://doi.org/10.5601/jelem.2013.18.4.455

Wyszkowska, J.; Kucharski, J.; Lajszner, W. 2006. The effects of copper on soil biochemical properties and its interaction with other heavy metals, Polish Journal of Environmental Studies 15(6): 927-934.
Yang, Z. X.; Liu, S. Q.; Zheng, D. W.; Feng, S. D. 2006. Effects of cadium, zinc and lead on soil enzyme activities, Journal of Environmental Sciences 18(6): 1135-1141. https://doi.org/10.1016/S1001-0742(06)60051-X

Yu, C.; Hu, X. M.; Deng, W.; Li, Y.; Xiong, C.; Ye, C. H.; Han, G. M.; Li, X. 2015. Changes in soil microbial community structure and functional diversity in the rhizosphere surrounding mulberry subjected to long-term fertilization, Applied Soil Ecology 86: 30-40. https://doi.org/10.1016/j.apsoil.2014.09.013

Zheng, N.; Liu, J.; Wang, Q.; Liang, Z. 2010. Health risk assessment of heavy metal exposure to street dust in the zinc smelting district, Northeast of China, Science of the Total Environment 408(4): 726-733. https://doi.org/10.1016/j.scitotenv.2009.10.075

Rafal STRACHEL. MSc Eng. He is a doctoral candidate. He is preparing his doctoral thesis in the Department of Microbiology in the Faculty of Environmental Management and Agriculture of University of Warmia and Mazury in Olsztyn. His scientific discipline is protection and management of the environment.

Jadwiga WYSZKOWSKA. Prof. Dr Hab. She is a full professor at UWM in Olsztyn. She obtained her PhD in 1996 and attained degrees for assistant professor in 2002 and professor in 2006. In 2005-2008, she was Associate Dean of the Faculty of Environmental Management and Agriculture, and in 2008-2012 she was Prorector of UWM in Olsztyn. Within the framework of scientific discipline of protection and management of the environment, she is specialised in soil biochemistry and environmental microbiology. In 2012-2015 she was the Chairman of the Section of Agricultural Microbiology in the Committee of Soil Science and Agricultural Chemistry of Polish Academy of Sciences (PAN).

Małgorzata BAĆMAGA. Dr Eng. She was granted her PhD from the Faculty of Environmental Management and Agriculture of University of Warmia and Mazury in Olsztyn in 2008. She is an associate professor in the Department of Microbiology in the Faculty of Environmental Management and Agriculture of University of Warmia and Mazury in Olsztyn. Her scientific discipline is protection and management of the environment, with the specialisation of soil microbiology. 